\title{
('LOSE OF JURASSIC AND OPENING OF CRETACEOUS TIME IN NORTH AMERICA ${ }^{1}$
}

\author{
BY HENRY FAIRFIELD OSBORN
}

(Presented before the Paleontological Society December 30, 1914)

\section{CONTENTS}

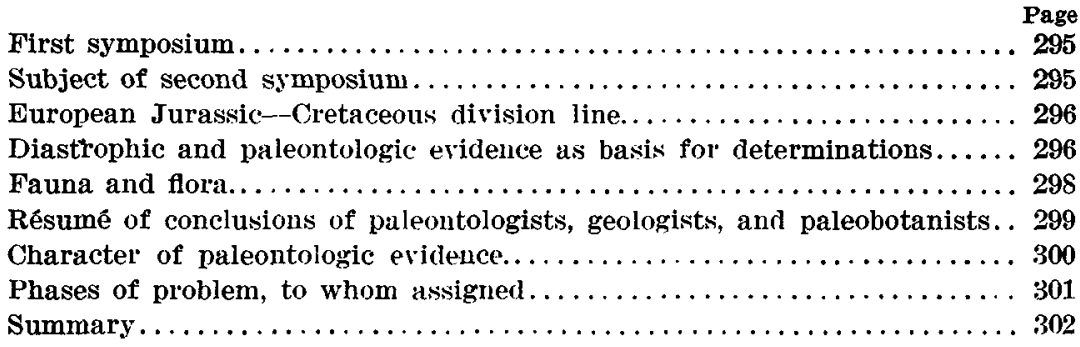

\section{E'IRST SYM MosILM}

A year ago the Paleontological and the Geological Societies united in a symposium on The Close of Cretaceous and Opening of Eocene Tim ${ }^{\circ}$ in North America. That symposium brought out very clearly the wide differences of opinion and practice now prevailing among American geologists and paleontologists as to the kinds of evidence on which we must chiefly rely in geologic and paleontologic correlation, chiefly as to the relative criteria of earth movements and of paleontology.

\section{Subjecri of Second Symposidum}

We are now met to discuss the characteristic features of another important period of geologic time. namely, the Jurassic-Cretaceous limits. as they have been iefinesl in lurope. from which, it ean not be too

\footnotetext{
1 This paper, which was delivered orally and has since been put in the present written form, is an introduction to the symposium on this subject held at the Philadelphia meetings of the two societies December $29-31,1914$. It is the second paleontological symposium presented before the two socleties in joint session. Manuscript recelved by the Secretary of the Geological Society July 2, 1915.
} 
strongly stated, we must take all our geologic time standards and demarkations. In this connection I would like to repeat the main statement in my address last year: "American events can be dated only by comparison of American with European faunas and floras, unless simultaneous and wor]d-wide diastrophic movements can be demonstrated to have occurred." This statement does not refer to the general diastrophic theory, which we are not now discussing, but to the attempt through appeal to the diastrophic theory to determine such boundaries as the Cretaceous-Eocene and Jurassic-Cretaceous hy reference to breaks in sedimentation which may be local rather than world-wide.

\section{European Jurassio-Crimachous Division Line}

In Europe the Jurassic-Cretaceous division line is by most geologists drawn between the fresh-water series of clays and sands in England known as the Wealden, and the underlying Purbeckian; in other words, the demarkation may be expressed as follows:

Base of the Cretaceous $=$ Wealden

Summit of the Jurassic $=$ Portlandian-Purbeckian

The problem before us in this symposium is, how can this old World stage of geologic time be most surely synchronized in the New World?

Having devoted mauy years to the special subject of correlation between the 'Tertiaries of linurope, Nortlı America, and sontheastern Asia, I. have formed the very strong personal opinion that in correlation between such periods and stuges as these we must rely chiefly on paleontology. 'I'his is for the very important umlerlying reason that the most stable, orderly, measurable, and coincident phenomena are those deepreated changes arising from the hereditary germ plasm which are ontwardly and visibly expressed in the various forms of animal and plant life. Paradoxical as it may sound, hereditary protoplasm is much more. stable than the surface of the eartl.

\section{Diastropinio and paleontologic Evidence as Basis for Determinations}

lising and falling coast or sedimentation lines in the pre-Tertiary and 'Tertiary, or even the larger earth movements causing true unconformities, such as the hirth of mountain systems and the earth changes incident thereto, may or may not be coincident in time in two continents on opposite sides of the world. As a matter of fact, we know that the successive orogenic movements or birthdays of many great mountain ranges, 
like the Rockies, the Pyrenees, the Alps, the Himalayas, have not been coincident in time. Similarly it remains to be shown that great coastal movements, such as those of America and Europe in Tertiary time, were coincident. Many are certainly known not to he coincident, and it follows that at least a very large percentage of disconformity and unconformity is not diastrophic in the broad sense in which the term is properly used.

On the other hand, the progressive and retrogressive evolution of animal and plant types on the two continents, or even on the four continents, presents a most impressive array of precisely or closely similar coincidences of precisely or nearly similar events in time. If any great or striking discords could be demonstrated between the rates of evolution of animals and of plants of similar descent in different continental areas then correlation through paleontology would largely break down; but uniform rates of evolution of organisms of similar ancestry even where widely soparated geographically is the prevailing law, notwithstanding that there are exceptional cases both of retardation and of acceleration.

It is absolutely necessary that those geologists who base their time determinations on appeals to the diastrophic theory should establish their first premise, namely, that the actual or alleged movements in America were coincident in time with similar diastrophic morements in Europe and Asia.

In the present Jurassic-Cretaccous problem it is necessary for the adherents of the diastrophic system of correlation to prove that large and coincident earth morements on both sides of the Atlantic marked the houndary between Jurassic and Cretaceous time. First, that at the close of the Jurassic a movement of elevation expelled the sea from the Rocky Mountain region, and that following this in Lower Cretaceous time a submergence took place. Second, that in England, where the close of the Jurassic and beginning of the Cretaceous was first clearly defined by paleontologists, a diastrophic movement took place during or immediately after the Purbeckian. Third, that in other parts of the world there are similar diastrophic boundaries between the Jurassic and Cretaceous.

To take but a single illustration: if we glance at the schematic section of the relations of the Jurassic and Cretaceous in Wiltshire, England, we find an entirely different set of conditions than those demanded by the diastrophists; not even the first condition is fulfilled, for the Jurassic, with its closing successive stages-the Kimeridgian, Portlandian, Purbeckian-passes gently and without marked change into the Wealden. There may be some disconformity; there is no angular unconformity. Only after the time interval between the Jurassic and. Cretaceous has 
long elapsed, namely, after the long Wealden stage, there occurs a great earth movement, and the succeeding Cretaceous stages are deposited horizontally on the sharply upturned basal Cretaceous, or Wealden.

This is clearly shown in the accompanying figure (figure 1), reproduced from Haug. ${ }^{2}$

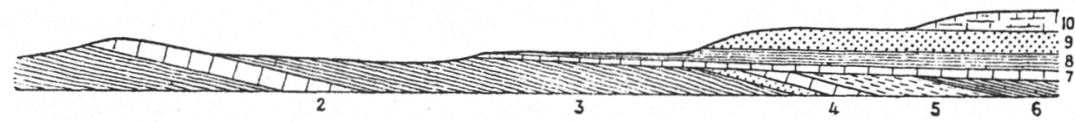

Furre: 1.- Reletions of the Jurussic (1-5) and the Cretaceous (6-10) in Wiltshirc, Funsland. (After II. H. Woolward and F. Hang)
9. Cenomanian (= Base of Upper Cretaceous).
8. Albian.
7. Aptlan.
(Great diastrophic movement, causing angular unconformity.)
6. Wealdian. Iguanodonts more specialized than those of the Morrison.
5. Purbeckian. Mammals similar to those of the Morrison.
4. Po!tlandian.
3. Kimeridgian. Iguanodonts similar to those of the Morrison.
2. Lusitanian.
1. Oxfordian. Marine invertebrate life similar to that of the Sundance. Sauropoda similar to the most primitive forms of the Morrison. 'Toothless ichthyosaurs, Opthatmosaulls, similar to the Sundance Buptanodon. Vertebrate and marine invertebrate fauna correlated with that of the Sundunce, which is referred by Stanton (1909) to the lower part of the Tuper Jurassic.
(Callovian.)

\section{FAUNA AND FIORA}

Now, let us examine more closely the European stages and their fauna. In the classification of D'Orbigny the last stage of the Jurassic system was designated under the name Portlandian, derived from Brongniart. "This," observes Hang (op. cit., page 10\%5), "can be extended to the upper Oölithic group by comprising within it the Purbeckian, which is simply a brackish facies of the superior portion of the Portlandian stage and which varies in thickness in different regions." Beneath the Portlandian is the Kimeridgian, beneath the latter the Lusitanian, and beneath this again the Oxfordian. It is in the Oxfordian that the earliest Sauropoda of the type of Cetiosanrus occur in Europe, a type of dinosaur which is in a stage of evolution similar to that of the Haplocanthosaurus of the Morrison of Cañon City, while within the Kimeridgian is found a species of iguanodont dinosaur known as Camptosaurus prestwichi, which is very similar (teste Gilmore) to the Camptosaurus nanus of the Morrison; in fact, all the camptosaurs of the Morrison are more generalized and primitive in structure than the iguanodonts of the Wealden.

\footnotetext{
2 F. Haug: "Traité de Géologie, vol. ii, Les Périọdes géologiques." 8vo. Armand Colin, Paris, 1908-1911, p. 1187.
} 
Having brought the charge against the earth-movement theory that no evidence has been adduced that at the close of Jurassic time similar great diastrophic movements took place in America and Europe, but that, on the contrary, there is a striking discordance in the periods of! diastrophism, I now desire to bring the charge against the paleontologists that those who have sought to solve this important and interesting question of the age of the MLorrison through paleontology have never done their work thoroughly; most of the paleontologists, myself included, have made hasty conclusions, based on incomplete examination and comparison of material which is rery rich and certainly affords ample basis lor more exact correlation than has yet been made. ${ }^{3}$ From the Morrison alone (the Jurassic or Lower Cretaceous age of which is in dispute) $151^{4}$ species of animals and plants have been named as follows:

Mammals, 25

Birds, 1

Sauropodous dinosaurs, $31(+3$ in Arundel of Maryland)

Carnivorous dinosaurs, $13(+3$ in Arundel of Maryland)

Armored dinosaurs. 10-11 $(+1$ in Arundel of Maryland)

Iguanodont dinosaurs, 14 (Camptosuurs) $(+1$ in Arundel of Marylaud )
Rhynchocephalians, 1

Crocodiles, $3(+1$ in Arundel of Maryland)

Turtles, 1

Pterosaurs, 1

Fish, 3

Species of invertebrates, $24(+4$ in Arundel of Maryland)

Species of plants, 23

Rénum ó of Conclasions of Paleontologists, Ghologists, and Pathobotanists

A vast literature has accumulated. In preparation for the geologic section alone of my monograph on the Sauropoda for the United States Geological Survey, my research assistant, Dr. Charles C. Mook, has listed 239 titles in the bibliography of the Morrison formation, the greater part of which deal with the geologic structure of the formation itself in different regions. There are, besides, a large number of papers on the Morrison fauma and flora, for we have over 300 titles on the Sauropodi alone. The conclusions which have been reached by the authors of these various contributions and of the papers in the following symposium are as follows:

\footnotetext{
${ }^{3}$ An exception to this statement may be made in favor of Prof. $\mathbf{S}$. W. Williston's excellent papel in the Journal of Geology for 1905 (vol. xili, May-June, pp. 338-350), in which he discusses the faunal relations of the Morrison.

4 The actual number of species js probally less than this as many of the species have been founded on fragmentary material and probably are synonyms.
} 
Morrison of Upper Jurassic Age

C. A. White, 1883, inver-tebrate paleontologist.

Edw. D. Cope, 1884, palcon tologist.

Henry F. Osborn, 1sis. paleontologist.

Lester F. Ward, 1900, paleobotanist.

Wilbur Knight, 1900, geol. ogist.

E. S. Riggs, 1901, paleontologist.

o. C. Marsh, 1836, paleontologist.

F. B. Loomis, 1901, paleontologist.

C. W. Gllmore, 1909, paleontologist.

W. J. Holland, 1912, paleontologist.

H. E. Gregory, 1914, geologist.
Morrison of both Upper Jurassic and Lower Cretaceous Age

J. B. Hatcher, 1903, geologist and paleontologist.

s. Wr. Williston, ${ }^{5}$ 1905, geologist and paleontologist.

IV. D. Matthew, ${ }^{\circ}$ geologist and paleontologist.

W. B. Scott, 1907 .

Chas. C. Mook, 1915, geologist.

T. W. Stanton, 1909, geologist and paleontologist.

T. W. Stanton, 1915.
Morrison chiefly of Comanchian or Lower Cretaceous Age

W. B. Scott, 1897, geologist and paleontologist.

S. F. Fmmons, 1896, geologist.

Logan, 1900, geologist.

N. H. Darton, 1915, geologist.

W. T. Lee, 1915, geologist.

E. W. Berry, 1915, paleobotanist and geologist.

\section{Character of paleontologic Evidence}

'The fact that the evidence from paleontology has thus far not been found conclusive is largely due, as stated above, to lack of thoroughness in the comparison both of the carnivorous and of the large herbivorous dinosaurs of the Morrison, which include forms resembling those which range from the Oxfordian through the Kimeridgian into the l'urbeckian and even into the Wealden. In gemeral, it is said the Morrison clinosians; are more specialized than those which lave been found in the trut: British Iurassic formations, but there are some very striking exceptions. The nammals appear to be closely related in their stage of evolution with those of the Purbeckian of Fngland. 'This would tend to correlate at least some parts of the Morrison with the Purbeckian of England as Tipper Jurassic. This was the main strength of Professor Marsl's argument. The invertebrate famna gives little satisfactory evidence as to age. The Morrison flora is scanty, consisting almost entirely of cycads. Lester F. Ward considered the cycads as proof of Jurassic age; but some-

\footnotetext{
IW. B. Scott: "An Introduction to Geology." 8vo. Macmillans, 1907, pp. 680-681. "It has been suggested by Professor Williston that different areas of the Morrison are of different dates, just as we saw that the Millstone Grit (Upper Carboniferous) of the Mississippi Valley is not a single uniform bed, but different beds of similar character, formed successively and corresponding to several horizons in the great mass of the Appalachian Pottsville. On this view, which is probably the solution of the problem, the Morrison includes several distinct horizons, extending from the Upper Iurassie into the Lower Cretaceous, but the discrimination of these horizons is yet to be made."

- Personal communication, 1915.
} 
what similar cycads have been found in beds which are almost certainly Comanchian, so the cycads can not be used to finally determine this question. The relation of the age of the Morrison formation to that of the Potomac beds of the East and of the Kootenie in the West is important. The lower member of the eastern Potomac carries a flora which is very similar to that of the Kootenie in Montana, and the Kootenic flora, as pointed out by Berry, is closely related to the other well known Comanchian floras. Geologically the stratigraphic relations certainly appear to favor Lower Cretaceous, or Comanchian, age for large portions of the Morrison.

\section{Phases of Problem, to whom Assigned}

I lave atlempted by way of introduction to very clearly state the prollem in regard to the age of the Morrison and the three auswers which have been given to this problem.

In the succeeding contributions to the symposium Mr. W. T. Lee, of the United States Geological Survey, will apply the earth-movement theory to the problem and treat the subject from the point of view of the paleophysiographer.

Dr. Charles C. Mook, of the American Museum of Natural History, will point out the vast area of the Morrison formation, its variations in thickness and in lithological character, with reference to its mode of origin and the general sources of the material of which the formation is composed. He will show that the actual age of the individual exposures of the Morrison formation in one locality may differ considerably from the age of the formation in another locality.

Prof. R. S. Lull, of Yale University, will characterize the Sauropola and Stegosauria of the Morrison, pointing out their means of mnigration anil comparing the three great regions in which Sauropoda have been discovered, namely, the Morrison of America, the Oxfordian to the Wealden of western Europe, and the beds at Tendaguru in East Africa. The African beds contain certain large and highly specialized dinosaurs (Brachiosaurus) similar to those in the Morrison; they are also reported to be partly associated with or underlying Jurassic (Kimeridgian, Oxtordian) marine invertebrates.

Finally, Dr. T. W. Stanton, of the United States Geological Survey, will treat the subject rather from the invertebrate paleontologic stancpoint in a comparison of the Morrison and the Comanchian in relation to the overlying and underlying formations in various parts of the western region. 


\section{StMMARY}

When these contributions are published and can be carefully compared, it will probably appear as the chief result of this symposium that the intermediate theory is correct; that, as long ago suggested by Prof. S. IT. Williston, the Morrison sedimentation was a very comprehensive and wide-spread process; that it began in certain localities earlier than in others, namely, during Upper Jurassic times; that it extended well into Lower Cretaceous times; that all the sediments known as Morrison represent a vast period of geologic time in which sedimentation was remarkably slow, because at no point does this so-called formation-which is rather a stage or series of stages in the European sense-attain any considerable thickness. The more primitive forms of Morrison life are partly, at least, truly Jurassic, while the more specialized progressive maybe are truly Lower Cretaceous. 